\title{
An Analysis of Financial Literacy and Household Saving among Fishermen in Indonesia
}

\section{Taofik Hidajat}

\author{
Doctoral Student at Padjadjaran University (UNPAD), Bandung \& Lecturer at STIE Bank BPD Jateng, Semarang \\ E-mail: inidotcom@yahoo.com
}

\author{
Doi:10.5901/mjss.2015.v6n5s5p216
}

\begin{abstract}
Financial literacy literatures suggested that people in many countries were financially illiterate. Even though financial literacy had quoted mostly in many research, this concept rarely examined on the population group of fishermen. The purpose of this study was to examine their personal financial literacy and the relationship between the financial literacy and household saving. The data for this study were gathered during January-June 2014 through questionnaires, conveniently distributed to a population group of fishermen in the age of 25 to 50 years old in Regency of Brebes, Tegal and Pekalongan, Central Java, Indonesia. Variables used in this study were financial literate and household saving. Results from 258 samples confirm that financial literacy was positively related to household saving. Eighty five percent of fishermen were illiterate and most of them had no saving account. We also find that financial inclusion played a crucial role to fishermen in saving their money. The results of this study suggested for policy makers to increase financial literacy of fishermen by implementing various financial education programs and financial inclusion by adding geographic penetration of banks and credit availability.
\end{abstract}

Keywords: financial literacy, financial illiteracy, financial inclusion, household saving, Indonesian fishermen

\section{Introduction}

Financial literacy is playing more important role in many countries associated with the various problems particularly global financial crisis. In some countries, financial literacy programs are carried out to make the people financially literate, so finally it will increase the prosperity and welfare.

Several conditions such as the ease of obtaining credit due to tighter competition of financial institutions (Beal \& Delpachitra, 2003) and the aggressiveness of marketing activities as well as the growth of financial products and services (Marcolin and Abraham, 2006) reinforce the assumption that financial literacy is a must.

Low financial literacy can be a serious problem for the households with because they tend to obtain the loan at high interest rate (Brown \& Graf, 2012; Gathergood, 2012; Lusardi and Tufano, 2009), They do not plan pension ( Bucher-Koenen and Lusardi, 2011; Lusardi \& Mitchell, 2005, 2011; MCJ van Rooij, Lusardi A., \& RJM Alessie, 2011), They do not diversify the low portfolio (Guiso \& Jappelli, 2008), and They have little amount of savings (Beckmann , 2013; Delafrooz \& Paim, 2011; Jappelli \& Padula, 2013; Kharchenko, 2011; Lusardi, 2008b; Mahdzan \& Tabiani, 2013; Spataro \& Corsini, 2013).

Some surveys have consistently shown the low level of financial literacy in the countries with high income. In the countries with middle and low income, the condition is even much lower (Xu \& Zia, 2012). Based on the research conducted by Cole, Sampson, and Zia (2009) in India and Indonesia, it was shown that financial literacy was low in both countries. Jappelli's study (2010) conducted in 55 countries including Indonesia from 1995 to 2008 concluded that there was a positive relationship between economic literacy with math skills (based on PISA tests). With test scores under 400, Indonesian economic literacy was considered as the low.

Jappelli (2010) also showed that the number population in urban areas was positively correlated to financial literacy. In several countries which the most population lives in the big cities (Australia, Belgium, Hong Kong, et cetera), a relatively high financial literacy is owned by their people. With the percentage of the urban population under $60 \%$, the economic and financial literacy of Indonesian society is under 4 or it is considered as relatively low.

The research conducted by DEFINIT (2013) also concluded that average Indonesian people had relatively low financial literacy index. The study involved 450 households in Medan, Jakarta and Surabaya. It also provided the conclusion that the higher the level of education and income, the higher level of financial literacy. In addition, low financial literacy level also correlated with less ownership of financial products such as stocks, bonds and mutual funds.

The lack of number of people who become customers of banks or investors in capital market was in line with the statement of Cole et al. (2009) that financial literacy was a predictor ofr demand for financial services. Low level of 
financial literacy was an obstacle to the use of financial services.

Several studies of financial literacy have been carried out on some object such as a student (Beal \& Delpachitra, 2003; Chen \& Volpe, 1998; Jang, Hahn, \& Park, 2014; Nidar \& Bestari, 2012), workers (Karunarathne \& Gibson, 2014) and households (Beckmann, 2013; Brown \& Graf, 2012; Harris, Loundes, \& Webster, 2002; Hilgert, Hogarth, and Beverly, 2003; Lusardi, 2008b; Van Rooij, Lusardi, and Alessie, 2012). However, the research on financial literacy in fishermen communities has not been conducted, yet.

This study was conducted to determine the influence of saving ownership financial literacy of fishermen communities in Indonesia. Fishermen communities was selected as the object besacuse it was bacgrounded by the real fact of their low economic welfare level. In addition, they still utilize very minimal banking services. The research question formulated was: "Does financial literacy among fishermen influence their household saving?"

\section{Literature Review}

There are many concepts of financial literacy ranging from financial awareness, financial knowledge, financial skills and financial ability that is, in practice, it is often overlapping ( $X u \&$ Zia, 2012). The terms of financial literacy, financial education and financial knowledge is often interchangeably in some literature (Huston, 2010).

In addition to the concepts and definitions which are still different, there has not been the standard instrument used to measure the level of financial literacy, yet (Huston, 2010). So, some researches on the theme of financial literacy used different assessment. Lusardi (2008) classified the level of financial literacy into two levels, basic and advanced.

Basic financial literacy includes knowledge about the level of interest rate, effects of inflation, and the concept of diversification of risk. While advanced financial literacy includes knowledge about relationship of risks and benefits; mechanism of bonds, stocks, and fund management and so underlying asset assessment.

Huston (2010) recommended that financial literacy measurement was done by using at least four basic domains, finance, borrowing, saving/investing and protection. While Bumcrot, Lin, and Lusardi (2013) measured the financial literacy index by using five questions about interest rates, inflation, risk diversification, the bond's price, and mortgages.

For the factors that influence financial literacy, few studies have been conducted to determine these factors. Several factors that are proven to have a significant effect was the work (Bhushan \& Medury, 2013; Worthington, 2006), age (Arrondel, Debbich, and Savignac, 2014; Beckmann, 2013; Lusardi \& Mitchell, 2011; Worthington, 2006), gender (Almenberg \& Dreber, 2012; Arrondel et al., 2014; Fonseca, Mullen, Zamarro, \& Zissimopoulos, 2012; Hassan Al-Tamimi and Al Anood Bin, 2009; Kharchenko, 2011; Lusardi \& Mitchell, 2008), education (Hassan Al- Tamimi and Al Anood Bin, 2009; Lusardi, 2008a; Mandell and Klein, 2009) and income (Bhushan \& Medury, 2013).

Several studies of financial literacy has been conducted by some objects of study. Related with financial decisions, some research on financial literacy had been conducted to determine the relationship of financial literacy and variables associated with financial decisions such as saving (Beckmann, 2013; Delafrooz \& Paim, 2011; Jappelli \& Padula, 2013; Kharchenko, 2011; Lewis \& Messy 2012; Lusardi, 2008b; Mahdzan \& Tabiani, 2013), retirement planning (BucherKoenen and Lusardi, 2011; Clark, 2012; Crossan, Feslier, \& Hurnard, 2011; Dvorak \& Hanley, 2010; Klapper \& Panos, 2011; Lusardi \& Mitchell, 2005; MCJ van Rooij et al., 2011), insurance (Mahdzan \& Victorian, 2013), investing in the stock market (Almenberg \& Dreber, 2011; Japalelli \& Padula, 2013; Müller \& Weber, 2009; Spataro \& Corsini, 2013; M. van Rooij, Lusardi A., and R. Alessie, 2011), and so on.

Previously, some studies on financial literacy had been carried out on some objects such as a student (Beal \& Delpachitra, 2003; Chen \& Volpe, 1998; Jang et al., 2014; Nidar \& Bestari, 2012), workers (Karunarathne \& Gibson, 2014) and households (Beckmann, 2013; Brown \& Graf, 2012; Harris et al., 2002; Hilgert et al., 2003; Lusardi, 2008b; Van Rooij et al., 2012). However, the research had not been conducted on financial literacy for fishermen communities. This study was conducted to bridge that gap. The hypothesis of research proposed was: Financial literacy influences savings ownership on fishermen household.

\section{Methodology}

The objective of this study was to determine whether financial literacy, influenced fishermen's household saving. Financial literacy level is the variable that will be calculated using measurements of the basic literacy level of Lusardi (2008a). Basic financial literacy includes knowledge about the level of interest rate, effects of inflation and concept of diversification of risk, namely:

1) Suppose you have Rp. 1.000,000 in a savings account and the interest rate is $5 \%$ per year. After 5 years, how much do you think you would have in the account if you left the money to grow: a. more than Rp 1.050.000; $b$. 
exactly $R p 1.000 .000 ;$ c. less than $R p 1.050 .000$ ?

2) Imagine that the interest rate on your savings account is $1 \%$ per year and inflation rate is $2 \%$ per year. After 1 year, would you be able to buy: a. More than; $b$. Exactly the same as; $c$. Less than today with the money in this account?

3) Do you think that the following statement is true or false? "Buying a single company stock, usually provides a safer return than a stock mutual fund."

The number of correct answers presented from to these questions will indicate the level of literacy. The higher (or lower) point obtained, the higher (or lower) level of financial literacy of the respondents. With three questions, the level of financial literacy that will be generated in this study were between 0-3. Household saving is the ownership of a bank savings products which were divided into two categories: (1) do not have savings, and (2) have savings.

The data for this study were collected through questionnaires during January-June 2014. They were conveniently distributed to a population group of fishermen in the age of 25 to 50 years old in Regency of Brebes, Tegal and Pekalongan, Central Java. The third area was chosen because it is the region harbors a lot of fish and fishing in Central Java. The sampling technique used was accidental sampling. To test the influence of financial literacy level on the ownership of financial products, analytical tools applied was logistic regression.

\section{Results and Discussion of Findings}

From this a study through 258 samples, it was described that the level of education of fishermen was very low. Fourteen percent of fishermen were high school graduates and the rest were not graduated from high school. They do not continue their education to a higher level of education because they come from poor fishing families who do not have money for school.

Table 1. Education Level of Fishermen

\begin{tabular}{|c|c|c|c|c|}
\hline & & Frequency & Percent & Valid Percent \\
\hline \multirow[t]{3}{*}{ Valid } & Graduate High School & 38 & 14.7 & 14.7 \\
\hline & $\begin{array}{l}\text { Not Graduate High } \\
\text { School }\end{array}$ & 220 & 85.3 & 85.3 \\
\hline & Total & 258 & 100.0 & 100.0 \\
\hline
\end{tabular}

The age of fishermen who went to sea to catch fish between was 25-40 years, while those aged over 40 years worked on the mainland to sell the catching results or doing odd jobs to repair the boat. They mostly did not have other skills that their free or idle time could not be utilized to generate additional income. Other family members, especially women also can not help because according Wasak (2012) fishermen work synonymous with men's work. Thus, vocational education should be given to fishing communities in order to be able to use their spare time to earn extra income.

Table 2. Financial Literacy Score

\begin{tabular}{|rl|r|r|r|r|}
\hline & & Frequency & Percent & Valid Percent & \multicolumn{2}{c|}{$\begin{array}{c}\text { Cumulative } \\
\text { Percent }\end{array}$} \\
\hline Valid & .00 & 12 & 4.7 & 4.7 & 4.7 \\
& 1.00 & 182 & 70.5 & 70.5 & 75.2 \\
& 2.00 & 24 & 9.3 & 9.3 & 84.5 \\
3.00 & 40 & 15.5 & 15.5 & 100.0 \\
& Total & 258 & 100.0 & 100.0 & \\
\hline
\end{tabular}

Eighty five percent of of fishermen were considered illiterate because they could not answer questions regarding basic financial literacy correctly. This fact is of concern because of low financial knowledge will make the fishermen could not take advantage of income received to save or invest.

They which were classified as literate were fishermen graduated from high school, stay in area with presence of school and financial institution in it, and having children who attend school activities. This shows that education is a way that can be used to solve problems of financial literacy as stated by Mandell, L., \& Klein, L. S. (2009). 


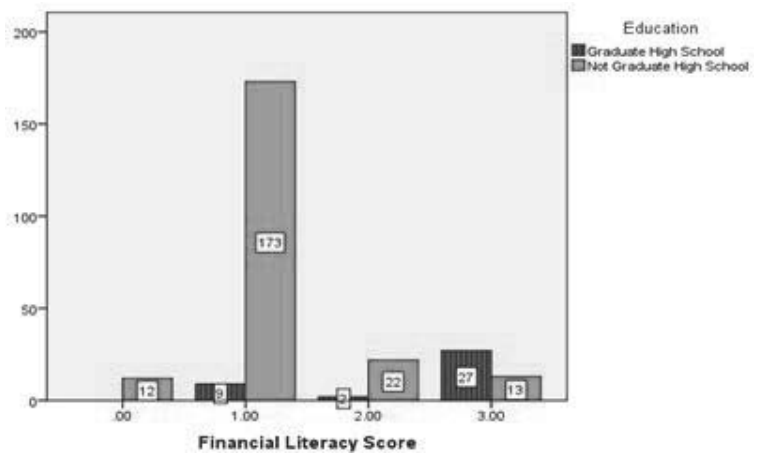

Figure 1. Financial Literacy Levels Based on Education

In addition, the area has a lot of schools and financial institutions also provide a role for financial literacy. Of the three regions, Pekalongan is an area that has a number of schools and financial institutions more than other regions and proved that the city has the highest level of financial literacy.
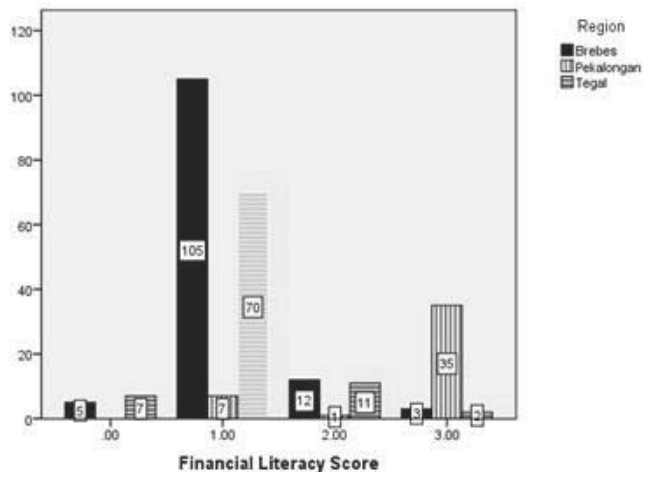

Figure 2. Financial Literacy Levels Based on Region

High financial literacy is also owned by those who have children in school. This shows that the higher the level of financial literacy, the higher the person's interest to send their children.

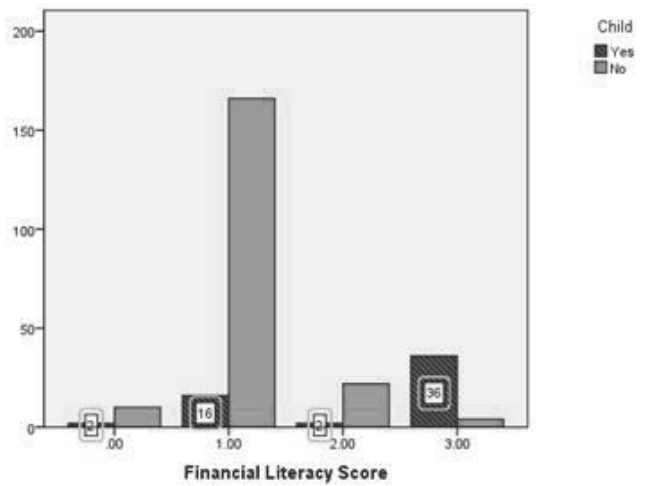

Figure 3. Financial Literacy Levels Based on Children Who Attend School Activity 
A regression equation analysis (Table 3 ) result that financial literacy is statistically significant due to have a smaller probability of $0.05(p<0,05)$. It can be concluded that the higher level of financial literacy, the higher opportunity to save income.

Table 3. Variables in the Equation

\begin{tabular}{|ll|r|r|r|r|r|r|}
\hline & \multicolumn{1}{|c|}{ B } & \multicolumn{1}{c|}{ S.E. } & Wald & \multicolumn{1}{c|}{ df } & \multicolumn{1}{c|}{ Sig. } & Exp(B) \\
\hline Step 1a & FinancialLiteracy & 2.321 & .289 & 64.406 & 1 & .000 & 10.186 \\
& Constant & -4.361 & .448 & 94.636 & 1 & .000 & .013 \\
\hline
\end{tabular}

a. Variable(s) entered on step 1: FinancialLiteracy.

Regression equations were derived from the results of these calculations are $Y=-4.361+2.321 x$. It means that if a person is not literate, then there would be no interest in saving. This is consistent with the results of research Beckmann (2013) and Jappelli \& Padula (2013) that low financial literacy will make someone have a little money to save. When a person becomes literate, then the probability of saving is equal to 1 or definitely will save. But it can only happen if a financial services institution is located closely to the place where they live. The characteristics of fishermen communities, especially in Regency of Brebes and Tegal are reluctant to come to a financial institution. They prefer to be served and it causes moneylenders more preferred by them. This is consistent with the study of Brown \& Graf (2012) and Gathergood (2012) that low financial literacy will make a person can borrow money at high interest rates.

\section{Conclusion and Limitation}

This study was conducted to examine financial literacy and the relationship between the financial literacy and household saving among Fishermen in Indonesia. This study found that of most fishermen in Indonesia have a low level of financial literacy as it also comes from a poor fishing family. This shows that education is a way that can be used to overcome poverty.

The study showed that they which were classified as literate were fishermen graduated from high school, stay in area with presence of school and financial institution in it, and having children who attend school activities. The study further showed that if a person is not literate, then there would be no interest in saving. But it can only happen if a financial services institution is located closely to the place where they live.

Nevertheless, this research still has limitations that sample size is still small, the choice of location, time and variable limited. Further research is recommended to investigate the literacy of selected aspects of behavior, especially regarding what would be done if the income of fishermen fishing gradually improved. In addition, other studies could also be carried out on women because of their fishermen who manage the family finances.

\section{References}

Almenberg, J., \& Dreber, A. (2011). Gender, stock market participation and financial literacy. Stockholm School of Economics Economic Research Institute Working Paper, 737.

Almenberg, J., \& Dreber, A. (2012). Gender, stock market participation and financial literacy. SSE/EFI Working Paper Series(737).

Arrondel, L., Debbich, M., \& Savignac, F. (2014). Financial literacy and financial planning in France.

Beal, D. J., \& Delpachitra, S. B. (2003). Financial literacy among Australian university students. Economic Papers: A journal of applied economics and policy, 22(1), 65-78.

Beckmann, E. (2013). Financial literacy and household savings in Romania. Numeracy, 6(2), 9.

Bhushan, P., \& Medury, Y. (2013). Financial literacy and its determinants. International Journal of Engineering, Business and Enterprise Applications, 4(2), 155-160.

Brown, M., \& Graf, R. (2012). Financial literacy, household investment and household debt: Evidence from Switzerland. Working Papers on Finance, 1301.

Bucher-Koenen, T., \& Lusardi, A. (2011). Financial literacy and retirement planning in Germany. Journal of Pension Economics and Finance, 10(04), 565-584.

Bumcrot, C., Lin, J., \& Lusardi, A. (2013). The geography of financial literacy. Numeracy, 6(2), 2.

Chen, H., \& Volpe, R. P. (1998). An analysis of personal financial literacy among college students. Financial Services Review, 7(2), 107128.

Clark, R. (2012). Financial literacy and retirement decisions: The choices facing older workers.

Cole, S. A., Sampson, T. A., \& Zia, B. H. (2009). Financial literacy, financial decisions, and the demand for financial services: evidence 
from India and Indonesia: Harvard Business School.

Crossan, D., Feslier, D., \& Hurnard, R. (2011). Financial literacy and retirement planning in New Zealand. Journal of Pension Economics and Finance, 10(04), 619-635.

DEFINIT. (2013). Developing an Indonesian Financial Literacy Index DEFINIT, Support for Economic Analysis Development in Indonesia (SEADI), and Otoritas Jasa Keuangan (OJK).

Delafrooz, N., \& Paim, L. H. (2011). Effects of demographic characteristics, financial literacy and management on saving behavior of Malaysian employees. Asia Life Sciences, 21(1).

Dvorak, T., \& Hanley, H. (2010). Financial literacy and the design of retirement plans. The Journal of Socio-Economics, 39(6), 645-652. doi: http://dx.doi.org/10.1016/j.socec.2010.06.013

Fonseca, R., Mullen, K. J., Zamarro, G., \& Zissimopoulos, J. (2012). What explains the gender gap in financial literacy? The role of household decision making. Journal of Consumer Affairs, 46(1), 90-106.

Gathergood, J. (2012). Self-control, financial literacy and consumer over-indebtedness. Journal of Economic Psychology, 33(3), 590602. doi: http://dx.doi.org/10.1016/j.joep.2011.11.006

Guiso, L., \& Jappelli, T. (2008). Financial literacy and portfolio diversification. EUROPEAN UNIVERSITY INSTITUTE, DEPARTMENT OF ECONOMICS.

Harris, M. N., Loundes, J., \& Webster, E. (2002). Determinants of household saving in Australia. Economic Record, 78(241), 207-223.

Hassan Al-Tamimi, H. A., \& Al Anood Bin, K. (2009). Financial literacy and investment decisions of UAE investors. The Journal of Risk Finance, 10(5), 500-516. doi: http://dx.doi.org/10.1108/15265940911001402

Hilgert, M. A., Hogarth, J. M., \& Beverly, S. G. (2003). Household financial management: The connection between knowledge and behavior. Fed. Res. Bull., 89, 309.

Huston, S. J. (2010). Measuring financial literacy. Journal of Consumer Affairs, 44(2), 296-316.

Jang, K., Hahn, J., \& Park, H. J. (2014). Comparison of financial literacy between Korean and U.S. high school students. International Review of Economics Education, 16, Part A(0), 22-38. doi: http://dx.doi.org/10.1016/j.iree.2014.07.003

Japalelli, T., \& Padula, M. (2013). Investment in Financial Literacy, Social Security and Porfolio Choice. (330). Centre for Studies in Economics and Finance.

Jappelli, T. (2010). Economic Literacy: An International Comparison*. The Economic Journal, 120(548), F429-F451.

Jappelli, T., \& Padula, M. (2013). Investment in financial literacy and saving decisions. Journal of Banking \& Finance, 37(8), 2779-2792. doi: http://dx.doi.org/10.1016/j.jbankfin.2013.03.019

Karunarathne, W., \& Gibson, J. (2014). Financial literacy and remittance behavior of skilled and unskilled immigrant groups in Australia. Journal of Asian Economics, 30(0), 54-62. doi: http://dx.doi.org/10.1016/.asieco.2013.12.004

Kharchenko, O. (2011). Financial Literacy in Ukraine: Determinants and Implications for Saving Behavior. Kyiv School of Economics.

Klapper, L., \& Panos, G. A. (2011). Financial literacy and retirement planning: the Russian case. Journal of Pension Economics and Finance, 10(04), 599-618.

Lewis, S., \& Messy, F.-A. (2012). Financial Education, Savings and Investments.

Lusardi, A. (2008a). Financial literacy: an essential tool for informed consumer choice? : National Bureau of Economic Research.

Lusardi, A. (2008b). Household saving behavior: The role of financial literacy, information, and financial education programs: National Bureau of Economic Research.

Lusardi, A., \& Mitchell, O. S. (2005). Financial literacy and planning: Implications for retirement wellbeing. Michigan Retirement Research Center Research Paper No. WP, 108.

Lusardi, A., \& Mitchell, O. S. (2008). Planning and financial literacy: How do women fare? : National Bureau of Economic Research.

Lusardi, A., \& Mitchell, O. S. (2011). Financial literacy and planning: Implications for retirement wellbeing: National Bureau of Economic Research.

Lusardi, A., \& Tufano, P. (2009). Debt literacy, financial experiences, and overindebtedness: National Bureau of Economic Research.

Mahdzan, N. S., \& Tabiani, S. (2013). The Impact of Financial Literacy on Individual Saving : An Exploratory Study In The Malaysian Context. Transformations in Business and Economics, 12(1).

Mahdzan, N. S., \& Victorian, S. M. P. (2013). The Determinants of Life Insurance Demand: A Focus on Saving Motives and Financial Literacy. Asian Social Science, 9(5), p274.

Mandell, L., \& Klein, L. S. (2009). The Impact of Financial Literacy Education on Subsequent Financial Behavior. Journal of Financial Counseling and Planning, 20(1), 15-24.

Marcolin, S., \& Abraham, A. (2006). Financial literacy research: Current literature and future opportunities. Paper presented at the 3rd International Conference on Contemporary Business, Leura NSW.

Müller, S., \& Weber, M. (2009). Financial Literacy and Mutual Fund Investments: Who Buys Actively Managed Funds? SBR.

Nidar, S. R., \& Bestari, S. (2012). Personal Financial Literacy Among University Students (Case Study at Padjadjaran University Students, Bandung, Indonesia). World, 2(4), 162-171.

Spataro, L., \& Corsini, L. (2013). Endogenous financial literacy, saving and stock market participation. MPRA Paper.

van Rooij, M., Lusardi, A., \& Alessie, R. (2011). Financial literacy and stock market participation. Journal of Financial Economics, 101(2), 449-472. doi: http://dx.doi.org/10.1016/j.jfineco.2011.03.006

Van Rooij, M. C., Lusardi, A., \& Alessie, R. J. (2012). Financial Literacy, Retirement Planning and Household Wealth*. The Economic Journal, 122(560), 449-478.

van Rooij, M. C. J., Lusardi, A., \& Alessie, R. J. M. (2011). Financial literacy and retirement planning in the Netherlands. Journal of 
Economic Psychology, 32(4), 593-608. doi: http://dx.doi.org/10.1016/j.joep.2011.02.004

Worthington, A. C. (2006). Predicting financial literacy in Australia. Financial Services Review, 57-79.

Xu, L., \& Zia, B. (2012). Financial literacy around the world: an overview of the evidence with practical suggestions for the way forward. The World Bank.

Wasak, M. (2012). Keadaan Sosial-Ekonomi Masyarakat Nelayan di Desa Kinabuhutan Kecamatan Likupang Barat. Kabupaten Minahasa Utara, Sulawesi Utara. PACIFIC JOURNAL, 1(7). 